\title{
Ribotyping and virulence markers of Yersinia pseudotuberculosis strains isolated from animals in Brazil
}

\author{
Carlos Henrique Gomes Martins/ ${ }^{+}$, Taís Maria Bauab*, Clarice Queico Fujimura Leite*, \\ Deise Pasetto Falcão*
}

\author{
Laboratório de Pesquisa em Microbiologia Aplicada, Universidade de Franca, Av. Dr. Armando Salles Oliveira 201, 14404-600 \\ Franca, SP, Brasil *Departamento de Ciências Biológicas, Faculdade de Ciências Farmacêuticas, Universidade Estadual Paulista, \\ Araraquara, SP, Brasil
}

\begin{abstract}
Ribotyping and virulence markers has been used to investigate 68 Yersinia pseudotuberculosis strains of serogroups $0: 1 a$ and $0: 3$. The strains were isolated from clinical material obtained from healthy and sick animals in the Southern region of Brazil. Ribotypes were identified by double digestion of extracted DNA with the restriction endonucleases SmaI and PstI, separation by electrophoresis and hybridization with a digoxigeninlabeled cDNA probe. The presence of the chromosomal virulence marker genes inv, irp1, irp2, psn, ybtE, ybtP$\mathrm{ybtQ}$, and ybtX-ybtS, of the IS100 insertion sequence, and of the plasmid gene lcrF was detected by polymerase chain reaction. The strains were grouped into four distinct ribotypes, all of them comprising several strains. Ribotypes 1 and 4 presented distinct profiles, with 57.3\% genetic similarity, ribotypes 2 and 3 presented 52.5\% genetic similarity, and genetic similarity was $45 \%$ between these two groups (1/4 and 2/3). All strains possessed the inv, irp1, and irp2 genes. Additionally, strains of serogroup O:1 a carried psn, ybtE, ybtP-ybtQ, ybtX$\mathrm{ybtS}$, and IS100. As expected lcrF was only detected in strains harboring the virulence plasmid. These data demonstrate the presence of $\mathrm{Y}$. pseudotuberculosis strains harboring genotypic virulence markers in the livestock from Southern Brazil and that the dissemination of these bacteria may occur between herds.
\end{abstract}

Key words: ribotyping - Yersinia pseudotuberculosis - virulence markers - polymerase chain reaction

Yersinia pseudotuberculosis can cause disease when it carries a set of plasmid- and chromosome-encoded virulence factors that facilitate colonization of the animal host and prevent the action of its specific and nonspecific defense mechanisms (Brubaker 1991).

Virulence properties of $Y$. pseudotuberculosis strains can be studied by the analysis of virulence factors coded by genes present on a virulence plasmid (pYV), the chromosomal gene (inv), and the genes located on the highpathogenicity island (HPI) (Cornelis 1994, Buchrieser et al. 1998a).

Invasiveness mediated by invasion proteins encoded by chromosomal genes is one of the main virulence mechanisms of pathogenic $Y$. enterocolitica and $Y$. pseudotuberculosis species. In Y. pseudotuberculosis, the ability of invasion is mediated by the protein Inv coded by the chromosome gene inv and the protein YadA coded by the plasmid gene yadA (Cornelis 1994, Carniel 1995).

The capacity to capture iron by means of endogenous or exogenous siderophores is another major virulence factor. In the three pathogenic Yersinia species, the genes

Financial support: Fapesp, grant 98/00984-9

${ }^{+}$Corresponding author: martinsc@ unifran.br

Received 13 December 2006

Accepted 21 May 2007 responsible for iron uptake are located in a chromosome region called the pathogenicity island. Since this region is only found in highly pathogenic Yersinia strains ( $Y$. enterocolitica $1 \mathrm{~B}$, Y. pseudotuberculosis $\mathrm{O}: 1$, and $Y$. pestis), it is referred to as the HPI (Carniel 1999). The HPI of $Y$. pestis and $Y$. pseudotuberculosis comprises a core consisting of 11 genes denominated psn; ybtE, T, U, A, $P, Q, X, S$; irpl and irp2, which are involved in the biosynthesis, regulation, and transport of the siderophore yersiniabactin. The HPI also carries genes encoding the insertion element IS 100 in Y. pestis and Y. pseudotuberculosis (Bach et al. 2000). The island is inserted in the bacterial chromosome at an asn-tRNA locus which contains a bacteriophage P4-like attachment site at its 3 '-end. Adjacent to this locus is a gene homologous to the integrase gene of bacteriophage P4 (Bach et al. 2000). The HPI of Y. pseudotuberculosis is serotype dependent. The complete HPI has only been found in serotype $\mathrm{O}: 1$. Serotype O:3 possesses an HPI that lacks a 9-kb portion on the left and carries the IS 100 sequence and genes $p s n$ and $y b t E$, whereas no HPI has been detected in the other serotypes tested $(\mathrm{O}: 2, \mathrm{O}: 4$ and $\mathrm{O}: 5)(\mathrm{Bu}-$ chrieser et al. 1998b).

Identification of the Yersiniae consists of biochemical and serological characterization (Aleksic \& Bockemuhl 1999). These procedures are time consuming and difficult to perform and the results are obtained slowly. Polymerase chain reaction (PCR) can identify bacteria to the species level and determine whether they are virulent or not.

In the present study, we ribotyped $Y$. pseudotuberculosis strains isolated in Brazil, associating ribotypes with virulence factors present on the HPI and plasmid pYV by PCR. 


\section{MATERIALS AND METHODS}

Bacterial strains - Sixty-eight Y. pseudotuberculosis strains isolated from sick and healthy animals were studied. These strains belong to the Culture Collection of the Yersinia Reference Laboratory (Coleção de Cultura do Laboratório de Referência em Yersinia) of the São Paulo State University (Unesp) at Araraquara and were received from 1982 to 1990 for confirmation and typing. The strains originally came from the Southern region of Brazil and were isolated by various researchers from the following institutions: Marcos Enrietti Diagnostic Center, Secretariat of Agriculture of the State of Paraná, Curitiba, PR; State University of Londrina, Londrina, PR, and Federal University of Pelotas, Pelotas, RS.

Ribotyping - DNA extraction and cleavage - DNA was extracted and cleaved as described by Popovic et al. (1993) and submitted to double digestion with the enzymes EcoRI/HindIII and SmaI/PstI. SmaI and PstI yielded the best fingerprint profiles for differentiation of the isolates and were used for DNA cleavage in all experiments.

Probe, DNA transfer and hybridization - The $16 \mathrm{~S}+23 \mathrm{~S}$ cDNA probe was prepared by reverse transcription of $16 \mathrm{~S}+23 \mathrm{~S}$ rRNA using the DIG DNA labeling and detection kit (Boehringer Mannheim, Germany), according to manufacturer instructions. For DNA transfer and hybridization with the probe, $2 \mu \mathrm{g}$ of DNA digest was electrophoresed on $0.8 \%$ agarose gel and transferred to nylon membranes by Southern blotting (Sambrook et al. 1989). The method used to label the $16 \mathrm{~S}+23 \mathrm{~S}$ rRNA and the detection and hybridization conditions has been described by Popovic et al. (1993).

Fingerprint analysis - Computer-assisted analysis of the ribotyping patterns was done by calculating the similarity coefficients. Cluster analysis was performed using the unweighted pair group method using arithmetic average (UPGMA). Genetic relatedness and divergence among ribotypes were calculated from a matrix defined on the basis of similarity between the distinct fingerprints (Sneath \& Sokal 1973) and are represented in a dendrogram constructed with the NTSYSpc software (Exeter Software, Stony Brook, NY, 1998). Groups of isolates showing identical fingerprints were designated as ribotypes.

Determination of virulence markers and of the IS100 sequence by PCR-DNA extraction - Genomic DNA was extracted and its concentration was determined as described by Nakajima et al. (1992). Briefly, colonies from blood agar were suspended in $100 \mu$ l distilled water in one tube to achieve a concentration of $10^{8} \mathrm{CFU} / \mathrm{ml}$. The cells suspensions were boiled for $10 \mathrm{~min}$ to expose (denature) the DNA. Aliquots of $5 \mu \mathrm{l}$ were then used as a template in the PCR.

Primers - The two sets of primers used in the multiplex PCR reactions targeting to $l c r F$ and inv genes are shown in Table I. Table II shows the primers used for the detection of the HPI genes and the size (in base pairs = bp) of the expected product. Y. pseudotuberculosis PB1 (serotype O1a) (Fukushima et al. 2001) was used as positive control. Reactions without DNA as template were used as negative controls.

Amplification - Amplification was performed in a 50 $\mu 1$ reaction mixture containing $0.5 \mathrm{U}$ of Taq DNA polymerase (Gibco BRL, Grand Island, NY, US), $100 \mu \mathrm{M}$ of each deoxynucleoside triphosphate (Gibco), $0.2 \mu \mathrm{M}$ of each primer (Gibco), and $5 \mu$ DNA. Thirty cycles of amplification were preformed in a thermal cycler (MJ Research, Watertown, MA, US). Each cycle consisted of pre-denaturation at $94^{\circ} \mathrm{C}$ for $1 \mathrm{~min}, 30$ cycles of denaturation at $94^{\circ} \mathrm{C}$ for $1 \mathrm{~min}$, primer annealing at $55^{\circ} \mathrm{C}$ for $1 \mathrm{~min}$, and extension at $72^{\circ} \mathrm{C}$ for $2 \mathrm{~min}$, followed by a final extension step at $72^{\circ} \mathrm{C}$ for $7 \mathrm{~min}$.

Visualization of the amplified products - The PCR products were electrophoresed in agarose gels stained with ethidium bromide $(0.5 \mu \mathrm{g} / \mathrm{ml})$ and visualized by UV light.

\section{RESULTS}

$Y$. pseudotuberculosis ribotypes - The 68 ribotyped strains were classified into four ribotypes (R1 to R4) defined by the number (four to seven) and the size $(<2.0$ to $23.1 \mathrm{~kb}$ ) of the fragments obtained by double digestion of the samples DNA with the enzymes SmaI and PstI.

Fig. 1 shows the four different ribotype profiles detected in the $68 Y$. pseudotuberculosis strains. Most of the strains $(52.9 \%)$ belonged to ribotype $1,20.6 \%$ to ribotype 3,16.2\% to ribotype 2 , and $10.3 \%$ to ribotype 4 .

Relationship among ribotypes - Percent similarity or genetic divergence among strains was calculated and is presented in the form of a dendrogram (Fig. 2). All ribotypes found included several strains. Ribotypes 1 and 4 showed different profiles and percent genetic similarity was $57.5 \%$. Ribotypes 2 and 3 presented $52.5 \%$ genetic similarity. Genetic similarity was $45 \%$ between these two groups (1/4 and 2/3).

TABLE I

Primers used in the multiplex polymerase chain reaction for detection of the $i n v$ and $l c r F$ genes

\begin{tabular}{lcccc}
\hline Target gene & Primer direction & Sequence $\left(5^{\prime} \rightarrow 3^{\prime}\right)$ & Amplicon length $(\mathrm{bp})$ & Reference \\
\hline$i n v$ & Forward & TAA GGG TAC TAT CGC GGC GGA & 295 & Nakajima et al. (1992) \\
& Reverse & CGT GAA ATT AAC CGT CAC ACT & & Wren \& Tabaqchali (1990) \\
\multirow{2}{*}{$\begin{array}{l}\text { ForF } \\
\text { Forward }\end{array}$} & TCA TGG CAG AAC AGC AGT CAG & 591 & \\
\hline
\end{tabular}


TABLE II

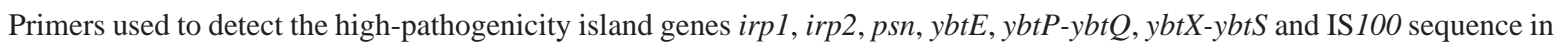
Yersinia pseudotuberculosis

\begin{tabular}{|c|c|c|c|c|}
\hline Target & Primer direction & Sequence $\left(5^{\prime} \rightarrow 3^{\prime}\right)$ & Amplicon length (bp) & Reference \\
\hline IS 100 & $\begin{array}{l}\text { Forward } \\
\text { Reverse }\end{array}$ & $\begin{array}{l}\text { ATT GAT CCA CCG TTT TAC TC } \\
\text { CGA ACG AAA GCA TGA AAC AA }\end{array}$ & 963 & $\begin{array}{l}\text { Podladchikova } \\
\text { et al. (1994) }\end{array}$ \\
\hline$p s n$ & $\begin{array}{l}\text { Forward } \\
\text { Reverse }\end{array}$ & $\begin{array}{l}\text { CTT TCC ACC AAC ACC ATCC } \\
\text { AAA CCG CCA CTT CGC TTC }\end{array}$ & 1,062 & $\begin{array}{l}\text { Buchrieser } \\
\text { et al. }(1998 b)\end{array}$ \\
\hline$y b t E$ & $\begin{array}{l}\text { Forward } \\
\text { Reverse }\end{array}$ & $\begin{array}{l}\text { CCC TTA CCC ATT GCC GAAC } \\
\text { TCC CCA CCT CAT CCA GCC }\end{array}$ & 1,198 & $\begin{array}{l}\text { Filippov } \\
\text { et al. (1995) }\end{array}$ \\
\hline irpl & $\begin{array}{l}\text { Forward } \\
\text { Reverse }\end{array}$ & $\begin{array}{l}\text { AGA AAC CGA TGC TCA CCC } \\
\text { TCC TCT CCT GAC GTA GCC }\end{array}$ & 526 & $\begin{array}{l}\text { Filippov } \\
\text { et al. (1995) }\end{array}$ \\
\hline irp2 & $\begin{array}{l}\text { Forward } \\
\text { Reverse }\end{array}$ & $\begin{array}{l}\text { AAG GAT TCG CTG TTA CCG GAC } \\
\text { TCG TCG GGC AGC GTT TCT TCT }\end{array}$ & 280 & $\begin{array}{l}\text { Schubert } \\
\text { et al. (1998) }\end{array}$ \\
\hline$y b t P-y b t Q$ & $\begin{array}{l}\text { Forward } \\
\text { Reverse }\end{array}$ & $\begin{array}{l}\text { GCC GGG AAC GTC AAA GAA } \\
\text { AGG TGA GCT TTC ATG TGC CT }\end{array}$ & 1,816 & $\begin{array}{l}\text { Bach } \\
\text { et al. }(2000)\end{array}$ \\
\hline$y b t X-y b t S$ & $\begin{array}{l}\text { Forward } \\
\text { Reverse }\end{array}$ & $\begin{array}{l}\text { TCA GTC GAA TGT GAAACC GC } \\
\text { GCA GCC GTG CCT GGC ACC CTT T }\end{array}$ & 1,453 & $\begin{array}{l}\text { Bach } \\
\text { et al. }(2000)\end{array}$ \\
\hline
\end{tabular}

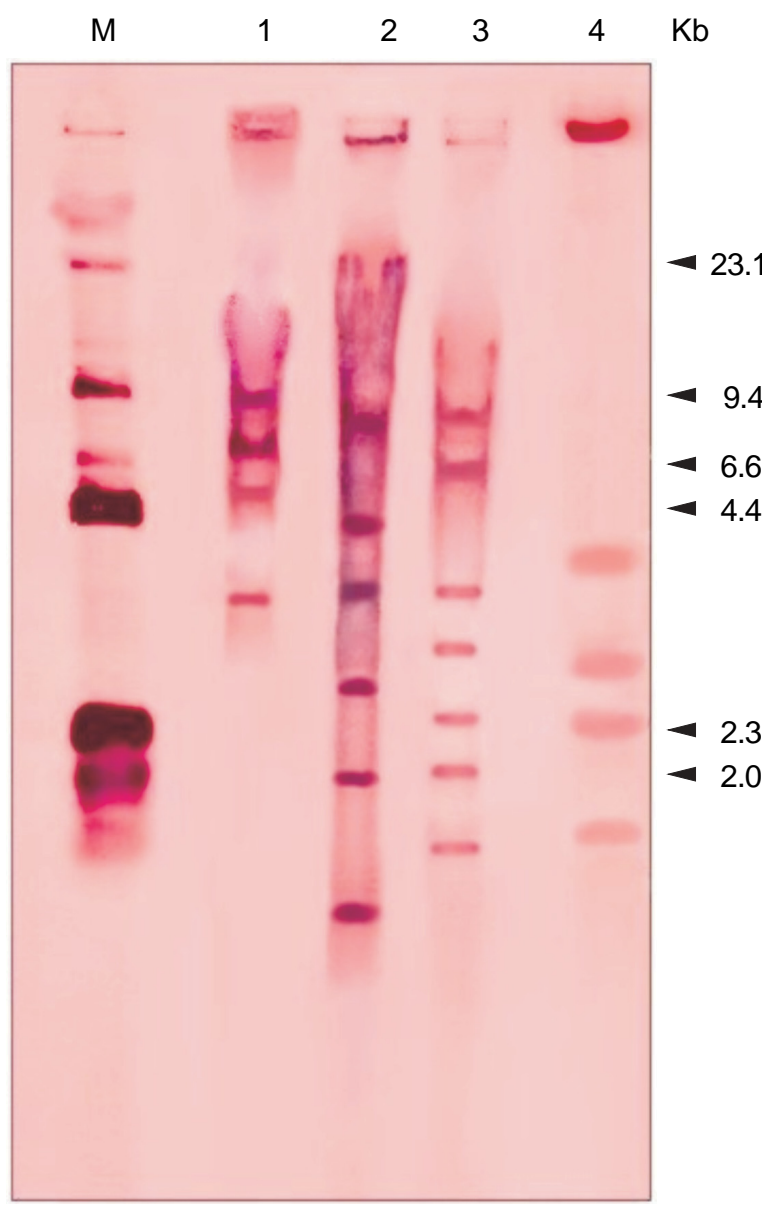

Fig. 1: ribotypes of Yersinia pseudotuberculosis strains observed after hybridization with digoxigenin-labeled 16+23S cDNA. Lanes - M: molecular mass marker (HindIII-digested $\lambda$ phage DNA); 1: ribotype 1 (36 strains); 2: ribotype 2 (11 strains); 3 : ribotype 3 (14 strains); 4 : ribotype 4 ( 7 strains).
Analysis of chromosomal and plasmid genes and of sequence IS100 - In the multiplex PCR essays the 68 strains amplified the 295-bp fragment expected for the chromosomal inv gene and 47 of them amplified the 591bp fragment expected for the $l c r F$ gene. These genes were detected in samples obtained from healthy and sick animals.

The other genes investigated ( $p s n, y b t E, y b t P-y b t Q$ and $y b t X-y b t S)$ and the IS 100 sequence were only detected in the two $Y$. pseudotuberculosis strains of biotype 1 and serogroup O:1a. The inv, irpl, and irp2 genes were detected in all strains studied.

Table III shows the distribution of ribotypes among all isolates according to bioserogroup and virulence markers.

\section{DISCUSSION}

In the present study, the $68 \mathrm{Y}$. pseudotuberculosis strains analyzed fited into four ribotypes (Fig. 1). Ribotype 1 was the most frequent (36 strains), followed by ribotype 3 , ribotype 2 , and ribotype 4 . Ribotype 1 and ribotype 4 showed $57.5 \%$ similarity.

No relationship was found between bioserogroups and ribotypes, although only two strains from the 1/O:1a bioserogroup were studied. These samples were classified as ribotype 1, together with 34 other strains from bioserogroup 2/O:3. In addition, no association could be established between the type of animal from which the strains were isolated and the ribotype, suggesting the circulation of $Y$. pseudotuberculosis in the environment and in different animal species. There was also no association between the ribotype and the geographical origin of the strains.

Isolation of $Y$. pseudotuberculosis cultures was carried out since 1982 in the state of Paraná and after 1989 in Rio Grande do Sul. The four ribotypes were detected in both states. These data suggest a common transmission vehicle for $Y$. pseudotuberculosis strains among animals in Paraná and Rio Grande do Sul. 


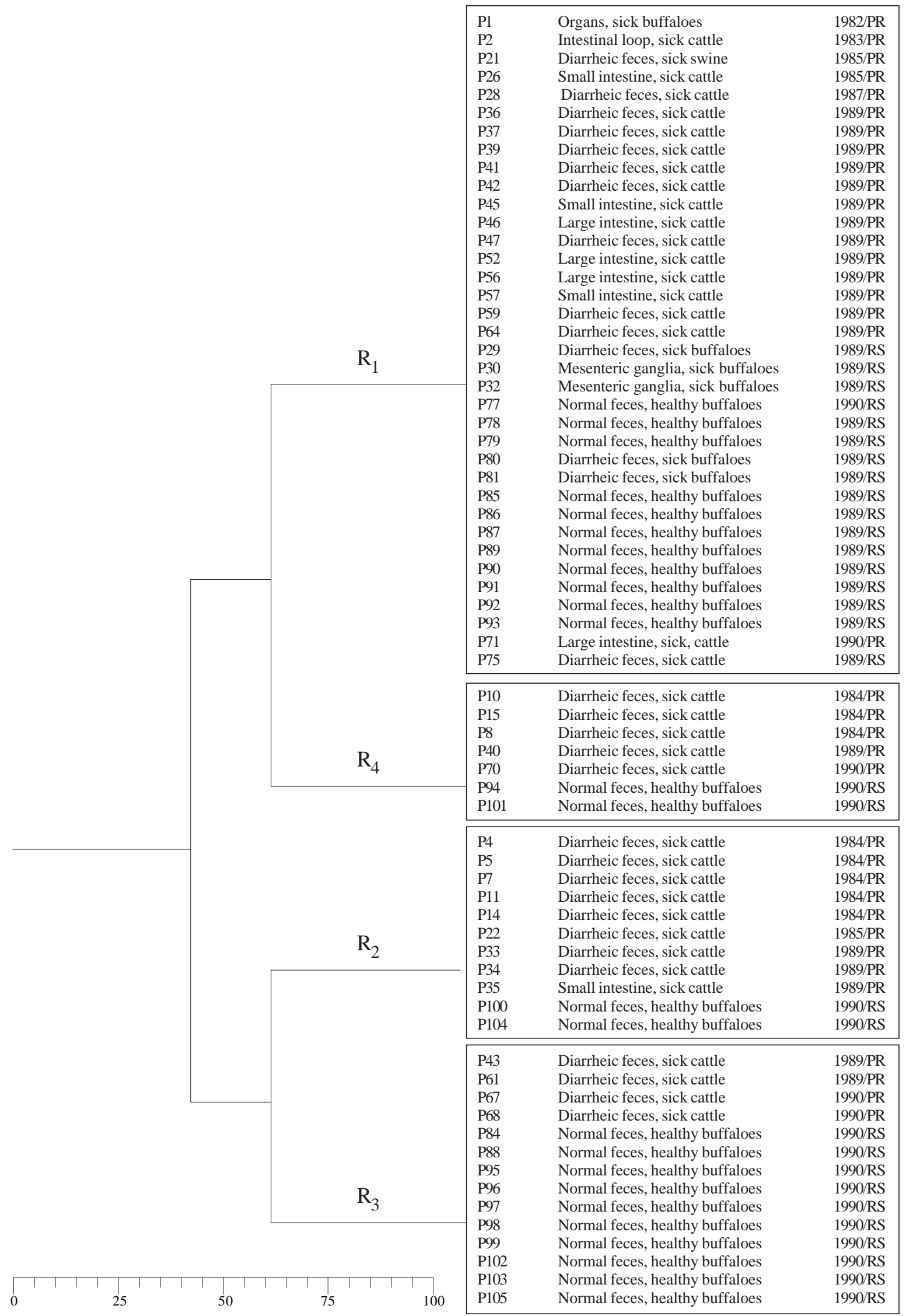

Fig. 2: dendrogram showing similarities among the ribotypes characterized for Yersinia pseudotuberculosis strains. The source of isolation, year and origin are shown for each strain. 
TABLE III

Distribution of the four ribotypes of the Yersinia pseudotuberculosis strains according to bioserogroup and virulence markers

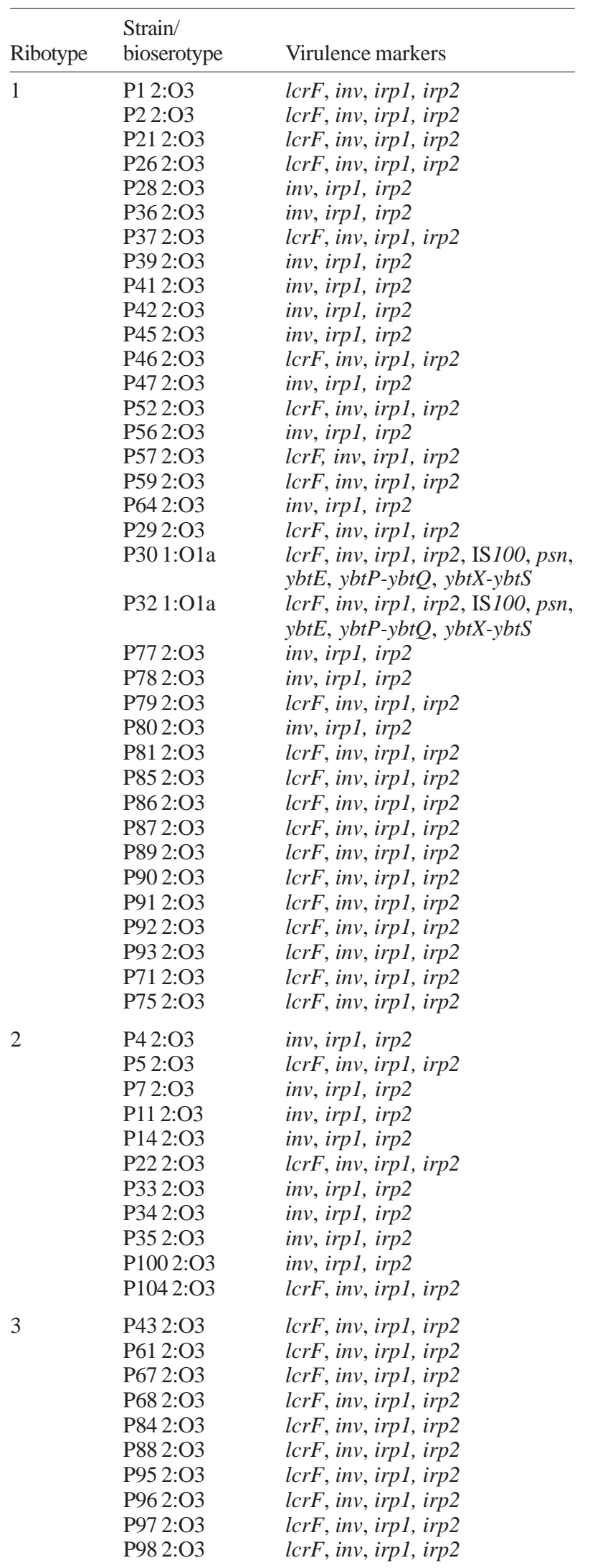

$\begin{array}{ll}\text { P99 2:O3 } & \text { lcrF, inv, irp1, irp2 } \\ \text { P102 2:O3 } & \text { lcrF, inv, irp1, irp2 } \\ \text { P103 2:O3 } & \text { lcrF, inv, irp1, irp2 } \\ \text { P105 2:O3 } & \text { lcrF, inv, irp1, irp2 } \\ \text { P102:O3 } & \text { lcrF, inv, irp1, irp2 } \\ \text { P15 2:O3 } & \text { lcrF, inv, irp1, irp2 } \\ \text { P8 2:O3 } & \text { lcrF, inv, irp1, irp2 } \\ \text { P402:O3 } & \text { lcrF, inv, irp1, irp2 } \\ \text { P702:O3 } & \text { lcrF, inv, irp1, irp2 } \\ \text { P942:O3 } & \text { inv, irp1, irp2 } \\ \text { P1012:O3 } & \text { lcrF, inv, irp1, irp2 }\end{array}$

It is known, that the main sources of these microorganisms are wild rodents and birds. Contamined water can cause major outbreaks among both humans and animals, with fecal-oral transmission being the main means of acces of these bacteria (Carniel \& Mollaret 1990).

Part of the $Y$. pseudotuberculosis strains studied here were isolated from healthy animals, suggesting that cattle and buffaloes may be carriers and disseminators of these bacteria. The ease transportation of animals between the two states may have also permitted the transmission of $Y$. pseudotuberculosis strains between them.

Multiplex PCR confirm the presence of the inv and lcr $F$ genes in samples that had been previously characterized biochemically and serologically, and in which the presence of pYV had been detected in a previous study (Martins et al. 1998). These data led us to conclude that this technique is a simple and fast tool for the detection of the inv and $l c r F$ genes (presents on the chromosome and in the pYV plasmid respectively) using primers directed to specific sequence of $Y$. pseudotuberculosis.

In this study all $Y$. pseudotuberculosis strains carried the inv, irpl and irp2 genes. The O:3 strains carried the inv, irpl and irp2 genes and had an incomplete HPI. This result is in agreement with published data showing that the right-hand part of the HPI contains a truncation of IS100 sequence and the $y b t E$ and psn genes in this serogroup (Buchrieser et al. 1998b).

The two $Y$. pseudotuberculosis O:1a strains additionally carried genes $p s n, y b t E, y b t P-y b t Q, y b t X-y b t S$, and the IS100 sequence, and were found to possess a complete HPI. In a previous in vivo infection kinetics study, these two samples exhibited higher pathogenicity since they were more virulent and invasive than biotype 2 and serogroup O:3 strains (Martins \& Falcão 2004). Fukushima et al. (2001), studying 2235 Y. pseudotuberculosis strains of various bioserotypes and origins isolated from different regions of the planet, showed that all strains of the O:1a serotype exhibited a complete HPI.

The $Y$. pseudotuberculosis strains of serogroup O:3 analyzed here showed a virulence potential, since all of them carried the irpl and irp 2 genes belonging to the pathogenicity island, and were isolated from both sick and healthy animals. According to Carniel et al. (1992), the irp 2 gene is a marker of high pathogenicity and is only found in pathogenic strains (Almeida et al. 1993). 
The absence of pYV in strains isolated from sick animals might be explained by the subsequent loss of this plasmid in some of these strains since they are stock cultures and have been frequently subcultured. On the other hand, the presence of the pathogenicity markers pYV and irp2 gene in $30.8 \%$ of the strains isolated from healthy animals suggest a pathogenic phenotype. These animals might develop the disease under unfavorable conditions such as cold weather and food shortage and favor environmental dissemination of these strains through their feces. Another hypothesis for the healthy condition of these animals is that they possess innate resistance to infection with $Y$. pseudotuberculosis (Hodges \& Carman 1985). Leal et al. (1997) phenotypically and genotypically characterizes some pathogenicity factors in $Y$. enterocolitica strains and observed the instability of some chromosomal segments in this bacterium. The authors attributed this instability to prolonged storage and manipulation after isolation, a fact indicating the importance for phenotypic and genotypic charcaterization of strains immediately after isolation.

\section{REFERENCES}

Aleksic S, Bockemuhl J 1999. Yersinia and other Enterobacteriaceae. In KV Forrest, JH Jorgensen, PR Murray, Manual of Clinical Microbiology, 7th ed., ASM Press, Washington, DC, p. 483-496.

Almeida AMP, Guiyoule A, Guilvout I, Iteman I, Baranton G, Carniel E 1993. Chromosomal irp2 gene in Yersinia: distribution, expression, deletion and impact on virulence. Microbiol Pathog 14: 9-21.

Bach S, Almeida AMP, Carniel E 2000. The Yersinia high-pathogenicity island is present in different members of the family Enterobacteriaceae. FEMS Microbiol Lett 183: 289-294.

Brubaker RR 1991. Factors promoting acute and chronic diseases caused by Yersiniae. Clin Microbiol Rev 4: 309-324.

Buchrieser C, Brosh R, Bach S, Guiyoule A, Carniel E 1998a. The high-pathogenicity island of Yersinia pseudotuberculosis can be inserted into any of the three chromosomal asn tRNA genes. Mol Microbiol 30: 965-978.

Buchrieser C, Prentice M, Carniel E 1998b. The 102-kilobase unstable region of Yersinia pestis comprises a high-pathogenicity island linked to a pigmentation segment which undergoes internal rearrangement. J Bacteriol 180: 2321-2329.

Carniel E 1995. Chromosomal virulence factors of Yersinia: an update. Contrib Microbiol Immunol 13: 218-224.

Carniel E 1999. The Yersinia high-pathogenicity island. Int Microbiol 2: 161-167.

Carniel E, Mollaret HH 1990. Yersiniosis. Comp Immunol Microbiol Infect Dis 13: 51-8

Carniel E, Guiyoule A, Guilvout I, Mercereau-Puijalon O 1992. Molecular cloning, iron-regulation and mutagenesis of the irp2 gene encoding HMWP2, a protein specific for the highly pathogenic Yersinia. Mol Microbiol 6: 379-388.

Cornelis GR 1994. Yersinia pathogenicity factors. Curr Top Microbiol Immunol 192: 243-263.

Filippov AA, Oleinikov PN, Motin VL, Protsenko OA, Sminov GB 1995. Sequencing of two Yersinia pestis IS elements IS285 and IS 100. Contrib Microbiol Immunol 13: 306-309.

Fukushima H, Matsuda Y, Seki R, Tsubokura M, Takeda N, Shubin FN, Paik IK, Zheng XB 2001. Geographical heterogeneity between far eastern and western countries in prevalence of the virulence plasmid, the superantigen Yersinia pseudotuberculosis-derived mitogen, and the high-pathogenicity island among Yersinia pseudotuberculosis strains. J Clin Microbiol 39: 3541-3547.

Hodges RT, Carman MG 1985. Recovery of Yersinia pseudotuberculosis from the faeces of healthy cattle. $N Z$ Vet $J 33$ : 175-176.

Leal, TCA, Leal NC, Almeida, AMP 1997. Marcadores de patogenicidade em Yersinia enterocolitica O:3 isoladas de suínos do Rio de Janeiro. Pesq Vet Bras 17: 19-24.

Martins CHG, Falcão DP 2004. Experimental kinetics of infection induced by Yersinia pseudotuberculosis isolated from stock animals. Mem Inst Oswaldo Cruz 99: 621-626.

Martins CHG, Bauab TM, Falcão DP 1998. Characteristics of Yersinia pseudotuberculosis from animals in Brazil. J Appl Microbiol 85: 703-707.

Nakajima H, Inoue M, Mori T, Itoh K-I, Arakawa AE, Watanabe H 1992. Detection and identification of Yersinia pseudotuberculosis and pathogenic Yersinia enterocolitica by an improved polymerase chain reaction method. J Clin Microbiol 30: 2484-2486.

Podladchikova ON, Dikhanov GG, Rakin AV, Heesemann J 1994. Nucleotide sequence and structural organization of Yersinia pestis insertion sequence IS100. FEMS Microbiol Lett 121: 269-274.

Popovic T, Bopp CA, Olsvik Ø, Kiehlbauch JA 1993. Ribotyping in molecular epidemiology. In DH Persing, FC Tenover, TF Smith, TJ White, Diagnostic Molecular Microbiology: Principles and Applications, ASM Press, Washington, DC, p. 573-583.

Sambrook J, Fritsch EF, Maniatis T 1989. Analysis of genomic DNA by Southern hybridization. In Molecular Cloning: A Laboratory Manual, Cold Spring Harbor Laboratory Press, New York, p. 382-389.

Schubert S, Rakin A, Karch H, Carniel E, Heesemann J 1998. Prevalence of the "high-pathogenicity island" of Yersinia species among Escherichia coli strains that are pathogenic to humans. Infect Immun 66: 480-485.

Sneath PHA, Sokal RR 1973. Numerical Taxonomy, WH Freeman, San Francisco, 532 pp.

Wren BW, Tabaqchali S 1990. Detection of pathogenic Yersinia enterocolitica by the polymerase chain reaction. Lancet 336: 693 . 